\title{
減衰を考慮した二層複合薄膜の一般化された一次元熱弾性解析*
}

\author{
芦 田 文 博*1, 須 見 尚 文*2 \\ 坂田誠一郎*1, 前田 真由子*3
}

\section{One-Dimensional Generalized Thermoelastic Analysis of a Two-Layered Composite Thin Film with Damping}

\author{
Fumihiro ASHIDA*4, Naobumi SUMI, \\ Sei-ichiro SAKATA and Mayuko MAEDA \\ ${ }^{* 4}$ Department of Electronic and Control Systems Engineering, Shimane University, \\ 1060 Nishikawatsu-cho, Matsue-shi, Shimane, 690-8504 Japan
}

\begin{abstract}
This paper deals with one-dimensional generalized thermoelasticity in a composite thin film constructed of a piezoceramic layer and a structural layer, when damping effect is taken into account. The film is initially at reference temperature and subjected to a ramp heating on the free surface of the piezoceramic layer. By applying Lord and Shulman's theory, the governing equations for the temperature changes, heat fluxes, particle velocities, axial stresses and electric field intensity are reduced to a system of nine first-order partial differential equations. This problem has been numerically analyzed by employing the method of characteristics. Finally, the effect of a damping coefficient on time histories of the temperature changes, axial stresses and electric field intensity are illustrated graphically.
\end{abstract}

Key Words : Elasticity, Thermal Stress, Thermal Shock, Numerical Analysis, Generalized Thermoelasticity, Piezoelectric Composite Film, Method of Characteristics

\section{1. 緒言}

圧電材料は, 電気場と弾性場の間の連成効果によって センサ機能やアクチュエータ機能を発現するために, ス マート構造物の素子として注目されている. 近年, ナノ オーダの厚さの圧電性薄募が開発され, 基板材料層に圧 電セラミックス層を重ねた機能性薄膜構造物が作成さ れるようになっている. このような薄膜に超高速レーザ が照射されたときや超音波が励起されたときなどには 熱衝揧現象が生じ易いため, 複合薄膜に生じる波動現象 を解明しておくことは，薄膜の動的強度を評価する上で 重要である.

薄膜などの熱衝撃問題では熱波と応力波の伝播速度 及び温度場とひずみ場の間の連成効果を考慮して解析 する必要性があり,これまで数多くの一般化された熱弾 性問題が解析されて来ている( () (). 圧電材料に関する 一般化された線形熱弾性理論は Chandrasekharaiah ${ }^{(3)}$ に

* 原稿受付 2007 年 8 月 30 日.

*1 正員, 島根大学総合理工学部 (690-8504 松江市西川津町 1060).

*2 正員, 静岡大学教育学部( 422-8529 静岡市駿河区大谷 836).

*3 富士通テン(株) (⑥52-8510 神戸市兵庫区御所通 1-2-28).

E-mail: ashida@ecs.shimane-u.ac.jp
よって確立された.この理論又は拡張された理論を適用 して, 圧電材料製の棒 ${ }^{(4)}{ }^{(6)}$ ，平板 ${ }^{(6)}$ 及び無限体や半 無限体のの一般化された熱弾性問題が解析されている. これらの報告では理論解析にラプラス変換法が適用さ れ, 逆変換は級数展開による方法または数值的な方法で 行われているため, 短時間内の数値結果しか示されてい ない：こ机対して，須見 ${ }^{(8)}$ は圧電材料平板の一般化 された熱弾性問題を特性曲線法によって解析し, 長時間 に瓦って数值結果を示している. ところで, 物体内を伝 播する応力波は粘弾性の影響により時間経過につれて 減衰するが，これまでに報告された論文ではこの減衰が 考慮されていないようである.

そこで, 本研究では, 基板材料層に圧電セラミックス 層が完全に接着された二層複合薄膜に熱衝撃が作用し た場合の一般化された一次元熱弾性を, 粒子速度の減衰 を考慮して解析を行っている. このとき, 粘弾性的特性 を表すために，減衰共鳴型の力学的モデル ${ }^{9)}$ を採用し た. 解析には特性曲線法を適用し, 温度変化, 応力及び 電界の強さを長時間にわたって数值的に求めた.ささらに, 粒子速度の減衰俰数や層厚比が, 温度変化, 応力及び電 界の強さの時間経過に及ぼす影響を明らかにした。 


\section{2. 問題設定と基礎方程式}

$2 \cdot 1$ 問題設定 図1に示すように, 厚さ $h_{p}$ の圧 電セラミックス層（結晶族 $6 \mathrm{~mm}$ ）が, 厚さ $h_{s}$ の基板材 料層 (等方性体) に完全に接着された二層複合薄膜を考 える. 初め基淮温度で一様な状態の複合薄鄚において, ある時間から圧電セラミックス層の自由表面 $(z=0)$ が急激に加熱されて表面の温度が $T_{c}$ だけ上昇し, 基板 材料層の自由表面 $(z=h)$ は基淮温度に保たれている ものと仮定する. このとき, 温度場の初期条件と境界条 件は，基準温度 $T_{0}$ からの温度変化を $T_{p}$ と $T_{s}$ とすると

$$
\begin{aligned}
& t=0 \text { で } T_{p}=T_{s}=0 \\
& z=0 \text { で }\left\{\begin{array}{l}
T_{p}=\left(t / t_{r}\right) T_{c}\left(0 \leq t \leq t_{r}\right) \\
T_{p}=T_{c}\left(t>t_{r}\right)
\end{array}\right. \\
& z=h_{p} \quad \text { で } T_{p}=T_{s}, q_{p z}=q_{s z} \\
& z=h \quad \text { で } T_{s}=0
\end{aligned}
$$

と与えられる. ここで, 添字 $p$ の付いた記号は土電セラ ミックス層に関する量を, 添字 $s$ の付いた記号は基板材 料層に関する量を表す.また， $q_{i 2}$ は熱流束， $t$ は時間, 及び $t_{r}$ はランプ爇の立ち上がり時間である.

一方，弾性場と電気場の境界条件は

$$
\begin{aligned}
& z=0 \quad \text { で } \quad \sigma_{p z z}=0, D_{p z}=0 \\
& z=h_{p} \text { で } \quad \sigma_{p z z}=\sigma_{s z z}, v_{p}=v_{s}, \quad D_{p z}=0 \\
& z=h \quad \text { で } \quad \sigma_{s z z}=0
\end{aligned}
$$

と表される. ここで, $\sigma_{i z z}$ は応力, $v_{i}$ は粒子速度, 及び $D_{p 2}$ は電束密度である. 尚, 本問題の場合, 圧電セラミ ックス層の電束密度は零となるため, 電気場の境界条件 は恒等的に満たされている.

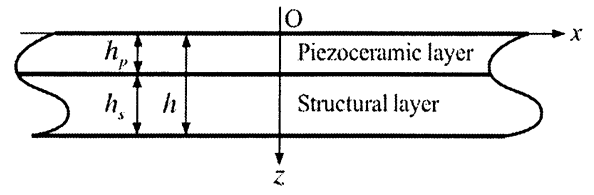

Fig. 1 Analytical model of a composite thin film

$2 \cdot 2$ 基礎方程式 Lord と Shulman ${ }^{(3)}$ (10) の一般 化された一次元熱弾性理論に基づき, 図 1 に示した二層 複合薄膜の解析を行う. 基板材料層において, 粒子速度 の減衰を考慮したときの運動方程式, 弾性場の構成方 程式，修正されたフーリエの法則，及び温度場と弾性 場の間の連成を考慮したときの熱伝導方程式は, 次に示 す通りである.

$$
\begin{aligned}
& \frac{\partial \sigma_{s z z}}{\partial z}-\rho_{s} \frac{\partial v_{s}}{\partial t}-\zeta_{s} v_{s}=0 \\
& \frac{\partial \sigma_{s z z}}{\partial t}-c_{s 33} \frac{\partial v_{s}}{\partial z}+\beta_{s 3} \frac{\partial T_{s}}{\partial t}=0 \\
& \tau_{s 0} \frac{\partial q_{s z}}{\partial t}+q_{s z}+k_{s 3} \frac{\partial T_{s}}{\partial z}=0 \\
& \frac{\partial q_{s z}}{\partial z}+\rho_{s} C_{s s} \frac{\partial T_{s}}{\partial t}+T_{c} \beta_{s 3} \frac{\partial v_{s}}{\partial z}=0
\end{aligned}
$$

ここで, $\rho_{i}$ は密度， $\zeta_{i}$ は粒子速度の減衰係数， $c_{i 33}$ は 弾性定数, $\beta_{i 3}$ は熱応力係数, $\tau_{i 0}$ は緩和時間, $k_{i 3}$ は熱 伝導率, 及び $C_{i v}$ は比熱である.

一方, 圧電セラミックス層において, 粒子速度の減衰 を考慮したときの運動方程式, 弾性場の構成方程式, 電気場の構成方程式，修正されたフーリエの法則，及 び温度場と弾性場の間の連成を考慮したときの熱伝導 方程式は, 次に示す通りである.

$$
\begin{aligned}
& \frac{\partial \sigma_{p z z}}{\partial z}-\rho_{p} \frac{\partial v_{p}}{\partial t}-\zeta_{p} v_{p}=0 \\
& \frac{\partial \sigma_{p z z}}{\partial t}-c_{p 33} \frac{\partial v_{p}}{\partial z}+e_{p 3} \frac{\partial E_{p z}}{\partial t}+\beta_{p 3} \frac{\partial T_{p}}{\partial t}=0 \\
& e_{p 3} \frac{\partial v_{p}}{\partial z}+\eta_{p 3} \frac{\partial E_{p z}}{\partial t}+p_{p 3} \frac{\partial T_{p}}{\partial t}=0 \\
& \tau_{p 0} \frac{\partial q_{p z}}{\partial t}+q_{p z}+k_{p 3} \frac{\partial T_{p}}{\partial z}=0 \\
& \frac{\partial q_{p z}}{\partial z}+\rho_{p} C_{p v} \frac{\partial T_{p}}{\partial t}+T_{c} \beta_{p 3} \frac{\partial v_{p}}{\partial z}=0
\end{aligned}
$$

ここで, $E_{p 2}$ は電界の強さ, $e_{p 3}$ は圧電係数, $\eta_{p 3}$ は誘電 率, 及び $p_{p 3}$ は焦電率である.

以上より, 本題は, 式 (1) - (7) の初期条件と境界 条件の下に, 式 (8) - (16) の9 個の偏微分方程式を 解いて, 9 個の末知量 $\sigma_{s z z}, v_{s}, T_{s}, q_{s z}, \sigma_{p z z}, v_{p}$, $T_{p}, q_{p z}$ 及び $E_{p z}$ を求める問題に帰着される.

\section{3. 特性曲線法による解析}

$3 \cdot 1$ 特性曲線方程式 基板材料層についての基 礎式 (8) - (11) 及び圧電セラミックス層についての 基礎式（12）一（16）をそれぞれ行列表示すると

$$
\begin{aligned}
& \mathbf{A}_{s} \frac{\partial \mathbf{w}_{s}}{\partial t}+\mathbf{B}_{s} \frac{\partial \mathbf{w}_{s}}{\partial z}+\mathbf{C}_{s}=\mathbf{0} \\
& \mathbf{A}_{p} \frac{\partial \mathbf{w}_{p}}{\partial t}+\mathbf{B}_{p} \frac{\partial \mathbf{w}_{p}}{\partial z}+\mathbf{C}_{p}=\mathbf{0}
\end{aligned}
$$

と表される.ここで，それぞれの行列 $\mathbf{w}_{i}, \mathbf{A}_{i}, \mathbf{B}_{i}$ 及

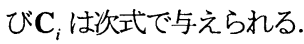




$$
\begin{aligned}
& \mathbf{w}_{s}=\left[\begin{array}{c}
v_{s} \\
\sigma_{s z z} \\
q_{s z} \\
T_{s}
\end{array}\right], \quad \mathbf{A}_{s}=\left[\begin{array}{cccc}
-\rho_{s} & 0 & 0 & 0 \\
0 & 1 & 0 & \beta_{s 3} \\
0 & 0 & \tau_{s 0} & 0 \\
0 & 0 & 0 & \rho_{s} C_{s v}
\end{array}\right] \\
& \mathbf{B}_{s}=\left[\begin{array}{cccc}
0 & 1 & 0 & 0 \\
-c_{s 33} & 0 & 0 & 0 \\
0 & 0 & 0 & k_{s 3} \\
T_{c} \beta_{s 3} & 0 & 1 & 0
\end{array}\right], \mathbf{C}_{s}=\left[\begin{array}{c}
-\zeta_{s} v_{s} \\
0 \\
q_{s z} \\
0
\end{array}\right] \\
& \mathbf{w}_{p}=\left[\begin{array}{c}
v_{p} \\
\sigma_{p z z} \\
E_{p z} \\
q_{p z} \\
T_{p}
\end{array}\right], \quad \mathbf{A}_{p}=\left[\begin{array}{ccccc}
-\rho_{p} & 0 & 0 & 0 & 0 \\
0 & 1 & e_{p 3} & 0 & \beta_{p 3} \\
0 & 0 & \eta_{p 3} & 0 & p_{p 3} \\
0 & 0 & 0 & \tau_{p 0} & 0 \\
0 & 0 & 0 & \rho_{p} C_{p v}
\end{array}\right] \\
& \mathbf{B}_{p}=\left[\begin{array}{ccccc}
0 & 1 & 0 & 0 & 0 \\
-c_{p 33} & 0 & 0 & 0 & 0 \\
e_{p 3} & 0 & 0 & 0 & 0 \\
0 & 0 & 0 & 0 & k_{p 3} \\
T_{c} \beta_{p 3} & 0 & 0 & 1 & 0
\end{array}\right], \mathbf{C}_{p}=\left[\begin{array}{c}
-\zeta_{p} v_{p} \\
0 \\
0 \\
q_{p z} \\
0
\end{array}\right]
\end{aligned}
$$

式（17）と（18）の連立偏微分方程式を解くために, 特性曲線法 ${ }^{(11)}$ を適用する. 基板材料層について,

$$
\operatorname{det}\left(\mathbf{A}_{s} \frac{d z}{d t}-\mathbf{B}_{s}\right)=0
$$

を解くと，4本の特性曲線が得られる.

$$
\frac{d z}{d t}= \pm V_{s 1}, \pm V_{s 2}
$$

これらの特性曲線に沿う特性曲線方程式は, 次の常微分 方程式で与えられる.

$$
\begin{gathered}
m_{1 i} \frac{d \sigma_{s z z}}{d t}-m_{2 i} \frac{d v_{s}}{d t}+m_{3 i} \frac{d q_{s z}}{d t}+m_{4 i} \frac{d T_{s}}{d t} \\
+m_{5 i} q_{s z}-m_{6 i} v_{s}=0 \quad(i=1 \sim 4)
\end{gathered}
$$

同様に，圧電セラミックス層についても，次のように

$$
\frac{d z}{d t}= \pm V_{p 1}, \pm V_{p 2}, 0
$$

5 本の特性曲線が得られ，これらの特性曲線に沿う特性 曲線方程式は, 次の常微分方程式で与えられる.

$$
\begin{gathered}
l_{1 i} \frac{d \sigma_{p z z}}{d t}-l_{2 i} \frac{d v_{p}}{d t}+l_{3 i} \frac{d q_{p z}}{d t}+l_{4 i} \frac{d T_{p}}{d t} \\
+l_{5 i} q_{p z}-l_{6 i} v_{p}=0 \quad(i=1 \sim 4), \\
l_{15} \frac{d \sigma_{p z z}}{d t}+l_{25} \frac{d E_{p z}}{d t}+l_{35} \frac{d T_{p}}{d t}=0
\end{gathered}
$$

ここで, $V_{s j}$ と $V_{p j}$ はそれぞれ基板材料層と圧電セラミ ックス層において導関数の不連続量が伝播する速度, $m_{j i}$ と $l_{j i}$ は既知の倸数行列である.

$3 \cdot 2$ 数值計算法 図 2 に示寸ように, 特性曲面 $(z, t)$ を圧電セラミックス層については特性曲線 $d z / d t= \pm V_{p 1}$ で, 基板材料層については $d z / d t= \pm V_{s 1}$ で それぞれ微小格子網に分割寸る. さらに, 図2 に例示し たように，圧電セラミックス層の格子網 DABC におい て, 格子点 $\mathrm{D}$ を通り傾き $d z / d t= \pm V_{p 2}$ の 2 本の特性曲


格子点 $\mathrm{D}$ を通る $d z / d t=0$ の特性曲線を含め, 合計 5 本 の特性曲線 $\mathrm{AD}, \mathrm{BD}, \mathrm{CD}, \mathrm{ED}$ 及び FD が得られる. これらの特性曲線に沿って式 (23) をそれぞれ数值積分 すると 5 元の連立方程式が導かれ，格子点 Dにおける 5 つの未知量 $v_{p}, \sigma_{p z z}, E_{p z}, q_{p z}$ 及び $T_{p}$ が求められる.

同様に，基板材料層についても， $d z / d t= \pm V_{s 1}$ と $d z / d t= \pm V_{s 2}$ に対応して, 4 本の特性曲線 GI と $\mathrm{HI}$ 及び JI と KI が得られる. 従って, これらの特性曲線に沿っ て式(21) を数值積分すると 4 元の連立方程式が導かれ， 格子点Iにおける4つの未知量 $v_{s}, \sigma_{s z z}, q_{s z}$ 及び $T_{s}$ が 求められる.

圧電セラミックス層と基板材料層との境界上では, 格 子点 $\mathrm{N}$ を通り傾きが $d z / d t=V_{p 2}$ の特性曲線を引き $\mathrm{LR}$ と交わる点を $\mathrm{P}$, 傾きが $d z / d t=-V_{s 2}$ の特性曲線を引き $\mathrm{MR}$ と交わる点を $\mathrm{Q}$ とする. 格子点 $\mathrm{N}$ を通る特性曲線 $\mathrm{LN}, \mathrm{PN}$ 及び $d z / d t=0$ に対寸る特性曲線 RN に沿って 式（23）を，特性曲線 MN と QN に沿って式 (21) を それぞれ数值積分し，式（3）と（6）の境界条件を適用 寸ると 9 元の連立方程式力導力氺，格子点 $\mathrm{N}$ における 9 つの未知量 $v_{p}$ と $v_{s}, \sigma_{p z z}$ と $\sigma_{s z z}, q_{p z}$ と $q_{s z}, E_{p z}$ 及び $T_{p}$ と $T_{s}$ が求められる.

圧電セラミックス層の自由表面上においては, 未知量 を求めるための特性曲線が 3 本となるが，式 (2) と (5) の境界条件より $T_{p}$ と $\sigma_{p z z}$ が規定されるため, 3 本の特性 曲線から導力れる 3 元の連立方程式を解くと, 残りの 3

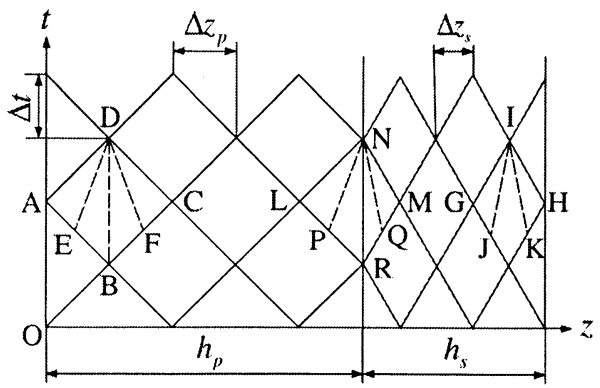

Fig. 2 Characteristic networks 
つの未知量 $q_{p z}, v_{p}$ 及び $E_{p z}$ が求められる.

同じように, 基板材料層の自由表面においても, 未知 量を求めるための特性曲線が 2 本となるが, 式 (4) と （7）の境界条件より $T_{s}$ と $\sigma_{s z z}$ が規定されるため, 2 本 の特性曲線加導力氺る 2 元の連立方程式を解くと, 残 りの 2 つの知量 $v_{s}$ と $q_{s z}$ が求められる.

\section{4. 数值計算}

$4 \cdot 1$ 計算条件 数值計算に当たり, 圧電セラミ ックス層と基板材料層にはそれぞれPZTと $\mathrm{MgO}$ を選ん だ. PZT-4の材料定数は

$$
\begin{aligned}
& \rho_{p}=7500 \mathrm{~kg} / \mathrm{m}^{3}, \quad C_{p v}=420 \mathrm{~J} / \mathrm{kgK} \\
& \alpha_{p z}=0.9 \times 10^{-5} 1 / \mathrm{K}, \quad c_{p 33}=115 \times 10^{9} \mathrm{~N} / \mathrm{m}^{2} \\
& \beta_{p 3}=3.6 \times 10^{6} \mathrm{~N} / \mathrm{Km}^{2}, \quad e_{p 3}=15.1 \mathrm{C} / \mathrm{m}^{2} \\
& \eta_{p 3}=5.62 \times 10^{-9} \mathrm{C}^{2} / \mathrm{Nm}^{2}, \quad k_{p 3}=2.1 \mathrm{~W} / \mathrm{mK} \\
& Y_{p z}=64.5 \mathrm{~N} / \mathrm{m}^{2}, \quad p_{p 3}=-2.12 \times 10^{-4} \mathrm{C} / \mathrm{Km}^{2} \\
& d_{p 2}=289 \times 10^{-12} \mathrm{C} / \mathrm{N}, \quad v_{p z}=3570 \mathrm{~m} / \mathrm{s}
\end{aligned}
$$

また, $\mathrm{MgO}$ の材料定数は

$$
\begin{aligned}
& \rho_{s}=3580 \mathrm{~kg} / \mathrm{m}^{3}, \quad C_{s v}=924 \mathrm{~J} / \mathrm{kgK} \\
& \alpha_{s z}=10.4 \times 10^{-6} 1 / \mathrm{K}, \quad c_{s 33}=286 \times 10^{9} \mathrm{~N} / \mathrm{m}^{2} \\
& \beta_{s 3}=4.78 \times 10^{6} \mathrm{~N} / \mathrm{Km}^{2}, \quad k_{s 3}=48.4 \mathrm{~W} / \mathrm{mK} \\
& Y_{s z}=2.454 \times 10^{11} \mathrm{~N} / \mathrm{m}^{2}, \quad v_{s z}=8279 \mathrm{~m} / \mathrm{s}
\end{aligned}
$$

である.ここで， $Y_{i z}$ は縦弾性係数， $\alpha_{i:}$ は線䐩長係数， 及び $v_{i z}$ は応力波の伝播速度である.

さて，これらの材料の緩和時間を調べてみたが，文 献に見当たらなかった. そこで, Francis ${ }^{(2)}$ のデー夕を 基に, 鋼とアルミニウムについて緩和時間から熱波の伝 播速度を計算してみると, 熱波の伝播速度は応力波の伝 播速度の約 $1 / 2$ 倍となった. また, 同文献より, 緩和時 間は概ね $10^{-11}-10^{-14}[\mathrm{~s}]$ の範用にあることが分かった。 そこで，本研究では，熱波と応力波の伝播速度の比が， 次の 3 通りの場合について数值計算を行った.

(1) $v_{p t}=2 v_{p z}, \quad v_{s t}=2 v_{s z}$

(2) $v_{p t}=v_{p z} / 2, \quad v_{s t}=v_{s z} / 2$

(3) $v_{p t}=v_{p z} / 10, \quad v_{s t}=v_{s z} / 10$

数値結果は, 圧電セラミックス層の厚さ $h_{p}$ を代表寸 法に, 次の無次元量で表す.

$$
\bar{z}=\frac{z}{h_{p}}, \quad\left(\bar{t}, \bar{t}_{r}, \bar{\tau}_{i 0}\right)=\frac{v_{p z}\left(t, t_{r}, \tau_{i 0}\right)}{h_{p}},
$$

$$
\begin{aligned}
& \bar{T}_{i}=\frac{T_{i}}{T_{c}}, \quad \bar{q}_{i z}=\frac{\kappa_{p} q_{i z}}{k_{p 3} v_{p z} T_{c}}, \quad \bar{v}_{i}=\frac{v_{i}}{\alpha_{p z} T_{c} v_{p z}}, \\
& \bar{\sigma}_{i z z}=\frac{\sigma_{i z z}}{Y_{p z} \alpha_{p z} T_{c}}, \quad \bar{E}_{p z}=\frac{d_{p z} E_{p z}}{\alpha_{p z} T_{c}}
\end{aligned}
$$

ただし, 基淮温度は $T_{0}=293 \mathrm{~K}$, ランプ加熱の立ち上 がり時間は $t_{r}=1.0 \times 10^{-12} \mathrm{~s}$ と仮定した. また, 粒子速 度の減衰係数を $\bar{\zeta}_{p}=\bar{\zeta}_{s}=0,0.02$ 及び 0.05 , 圧電セ ラミックス層と基板材料層の厚さの比を $\bar{h}_{p} / \bar{h}_{s}=1 / 5$, $1 / 10,1 / 15$ 及び $1 / 20$ として, 数值計算を行った.
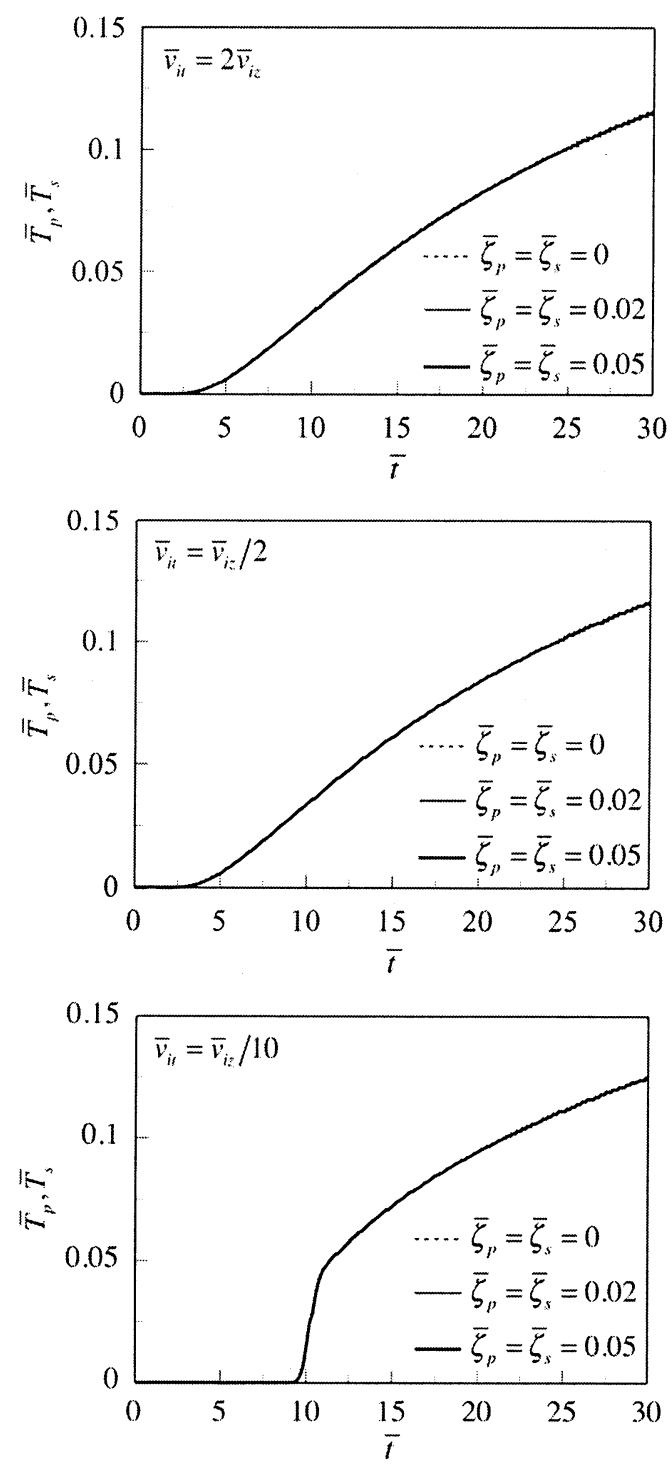

Fig. 3 Effect of damping coefficient on temperature changes at $\bar{z}=1.0$ for $\bar{h}_{p} / \bar{h}_{s}=1 / 5$ 
$4 \cdot 2$ 数值結果 圧電セラミックス層と基板材料 層の厚さの比が $\bar{h}_{p} / \bar{h}_{s}=1 / 5$, 熱波の伝播速度が $\bar{v}_{i t}=(2,1 / 2,1 / 10) \bar{v}_{i z}$ の場合について, 粒子速度の減 衰係数が圧電セラミックス層と基板材料層との境界上 $(\bar{z}=1.0)$ における温度変化, 応力及び電界の強さの 時間経過に及ぼす影響を図 3-5にそれぞれ示す。図 3 より，熱波の伝播速度にかかわらず, 粒子速度の減衰係 数は温度変化の時間経過にほとんど影響を及ぼしてい ない. また, 温度変化の時間経過は $\bar{v}_{i t}=2 \bar{v}_{i z}$ のときと $\bar{v}_{i t}=\bar{v}_{i z} / 2$ のときに相違は見られないが， $\bar{v}_{i t}=\bar{v}_{i z} / 10$ のときには温度変化が大きくなり始める時間が遅くな
るとともに，急激に大きくなっている. 図4と5より, 熱波の伝播速度にか加わらず, 減衰を考慮すると時間経 過につれて応力と電界の強さは減衰し, 粒子速度の減衰 係数が大きくなると応力と電界の強さのピーク值の減 衰が著しくなっている. また, 熱波の伝播速度が $\bar{v}_{i t}=\bar{v}_{i z} / 10$ の場合は, 他の二つの場合に比べて, 応力 と電界の強さの時間経過が緩やかで, ピーク值も小さい. 尚, 図 4 の $\bar{v}_{i t}=2 \bar{v}_{i z}$ の場合において, 減衰係数が零の ときでも応力が時間経過につれてわずかに減衰してい るが,これは温度場とひずみ場の間の連成効果の影響に よるものである.この連成効果の影響は, 熱波の伝播速
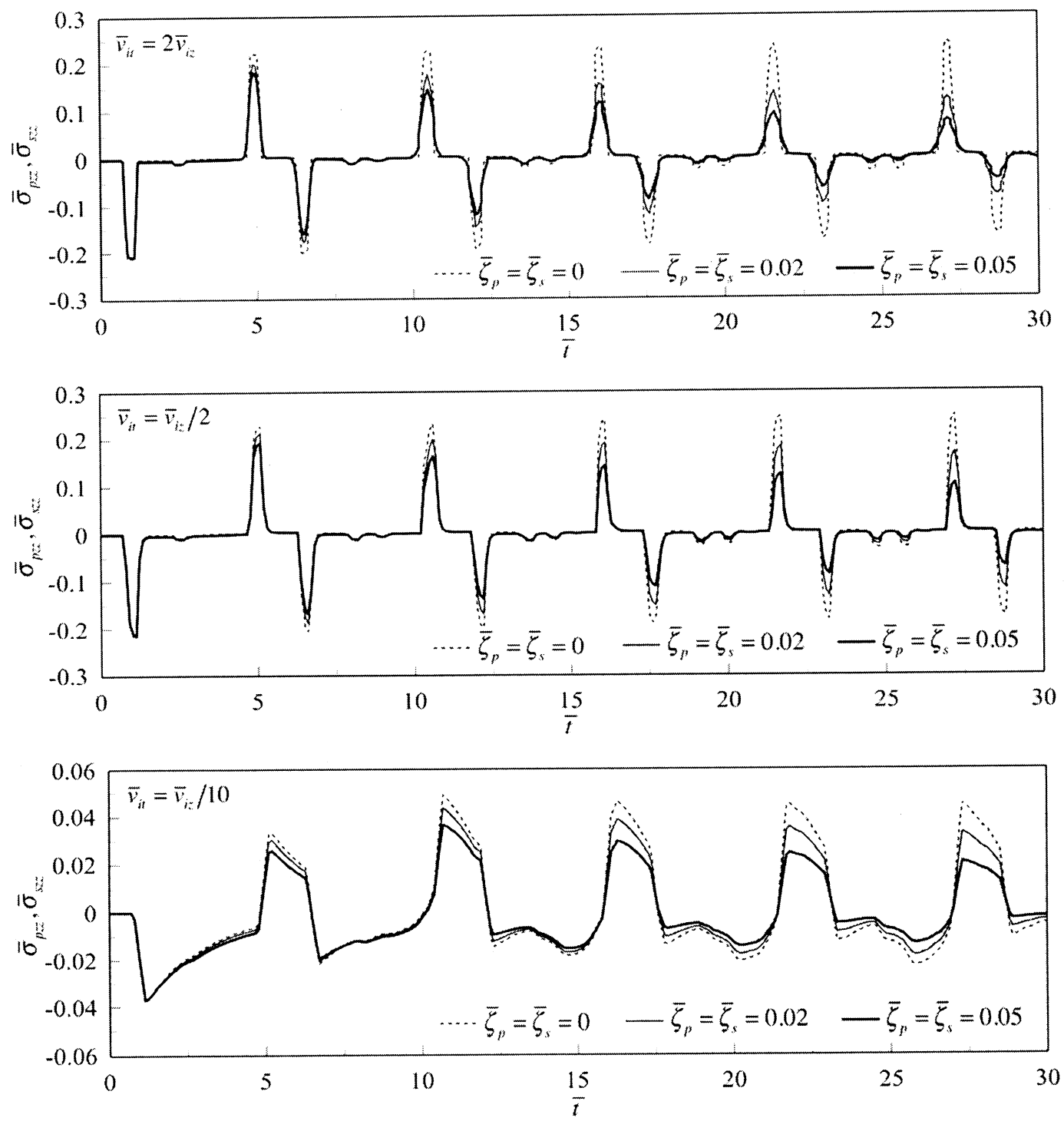

Fig. 4 Effect of damping coefficient on stresses at $\bar{z}=1.0$ for $\bar{h}_{p} / \bar{h}_{s}=1 / 5$ 



Fig. 5 Effect of damping coefficient on electric field intensity at $\bar{z}=1.0$ for $\bar{h}_{p} / \bar{h}_{s}=1 / 5$

度が応力波より遅い場合にはほとんど見られない。

減衰倸数が $\bar{\zeta}_{p}=\bar{\zeta}_{s}=0.05$, 熱波の伝播速度が $\bar{v}_{i t}=\bar{v}_{i z} / 2$ の場合について, 圧電セラミックス層と基板 材料層の層さの比が圧電セラミックス層と基板材料層 との境界上 $(\bar{z}=1.0)$ における温度変化, 応力及び電界 の強さの時間経過に及ぼす影響を図6に示寸.図6より, 層厚の比は温度変化の時間経過にほとんど影響を及ぼ していない, 一方, 層厚の比は応力と電界の強さの時間 経過に大きく影響を及ぼし, 基板材料層が厚くなるのに つれて応力と電界の強さのピーク数は减少している.
減衰係数が $\bar{\zeta}_{p}=\bar{\zeta}_{s}=0.05$, 熱波の伝播速度が $\bar{v}_{i t}=\bar{v}_{i z} / 2$, 圧電セラミックス層と基板材料層の厚さの 比が $\bar{h}_{p} / \bar{h}_{s}=1 / 5$ 場合について, 圧電セラミックス層 と基板材料層内の数点における温度変化, 応力及び電界 の強さの時間経過を図 7 に示寸. 図 7 より, 加熱面 $(\bar{z}=0)$ から離れるのにつれて, 温度変化と電界の強 さは小さくなり, 零に近づいている. 一方, 応力の場合 は自由境界面からある程度離れると, 応力のピーク值は 位置によって大きさがあまり変わらず, 時間経過につれ て減衰している. 

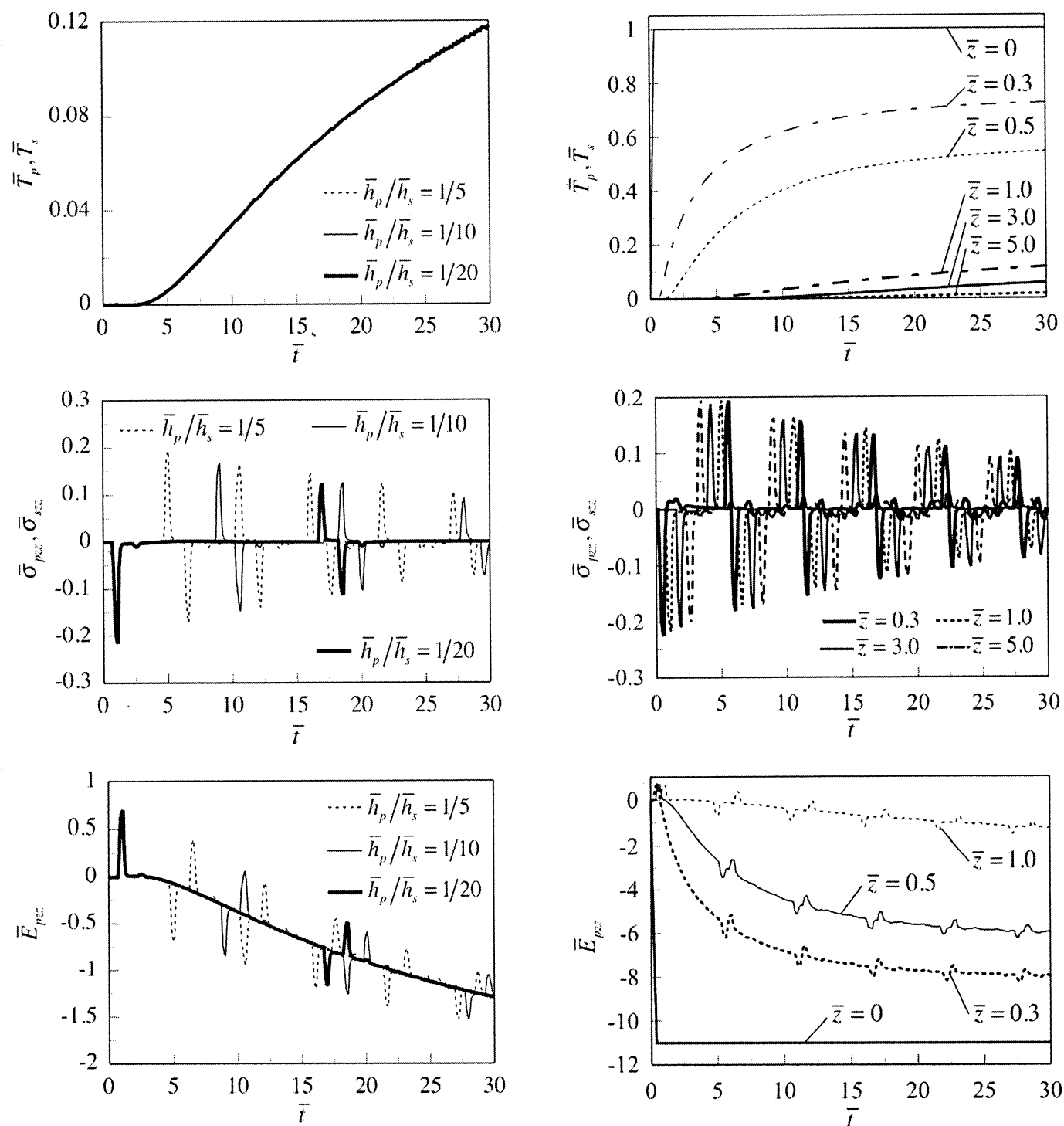

Fig. 6 Effect of thickness ratio of layers on temperature changes, stresses and electric field intensity at $\bar{z}=1.0$ for $\bar{\zeta}_{p}=\bar{\zeta}_{s}=0.05$ and $\bar{v}_{i t}=\bar{v}_{i z} / 2$

\section{5. 結言}

本研究で得られた解析結果と数值結果をまとめると, 次の通りである.

（1）結晶族 $6 \mathrm{~mm}$ の圧電材料層と等方性基板材料層と で構成された二層複合薄膜において, 減衰共鳴型の力学 的モデルによって粒子速度の減衰を考慮した場合の一 般化された熱弾性問題は, 特性曲線法によって解析でき ることが示された.

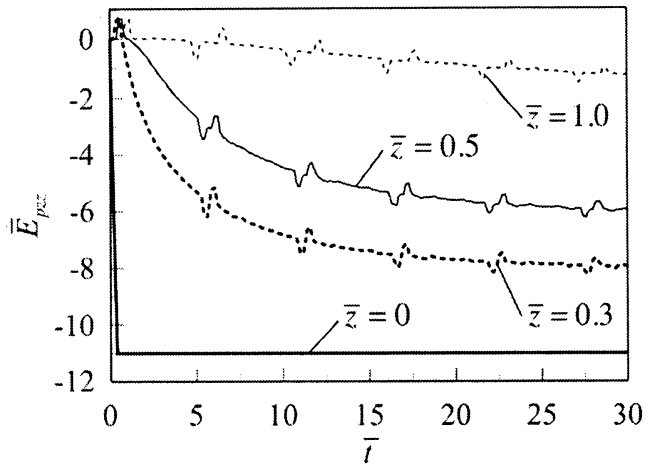

Fig. 7 Temperature changes, stresses and electric field intensity at various points for $\bar{\zeta}_{p}=\bar{\zeta}_{s}=0.05$, $\bar{v}_{i t}=\bar{v}_{i z} / 2$ and $\bar{h}_{p} / \bar{h}_{s}=1 / 5$

（2）応力と電界の強さには波動が現九たが，温度変化 には波動が現れなかった. また, 粒子速度の減衰係数は 温度変化にほとんど影響を及ぼさないが, 応力と電界の 強さは粒子速度の減衰係数が大きくなるのにつれて早 く減衰寸ることが示され, 妥当な数值結果が得られた.

（3）熱波の伝播速度が $\bar{v}_{i t}=\bar{v}_{i z} / 10$ と遅い場合は, 速い 場合に比べて, 温度変化が遅くなり, また応力と電界の 強さは時間経過に対して比較的緩やかに变化し，ピーク 值も小さくなることが示された. 


\section{文献}

(1) Chandrasekharaiah, D. S., Thermoelasticity with Second Sound: A Review, Transactions of the ASME, Applied Mechanics Reviews, Vol. 39, No. 3(1986), pp. 355-376.

(2) Chandrasekharaiah, D. S., Hyperbolic Thermoelasticity: A Review of Recent Literature, Transactions of the ASME, Applied Mechanics Reviews, Vol. 51, No. 12 (1998), pp. 705- 729.

(3) Chandrasekharaiah, D. S., A Generalized Linear Thermoelasticity Theory for Piezoelectric Media, Acta Mechanica, Vol. 71, No.1-4 (1988), pp. 39-49.

(4) El-Karamany, A. S. and Ezzat, M. A., Propagation of Discontinuities in Thermopiezoelectric Rod, Joumal of Thermal Stresses, Vol. 28, No.10 (2005), pp. 997-1030.

(5) He, T., Tian, X. and Shen Y., State Space Approach to One-Dimensional Thermal Shock Problem for a Semi-Infinite Piezoelectric Rod, International Journal of Engineering Science, Vol. 40, No.10 (2002), pp. 1081-1097.

(6) He, T., Tian, X. and Shen Y., Two-Dimensional Generalized Thermal Shock Problem of a Thick Piezoelectric Plate of Infinite Extent, International Joumal of Engineering Science, Vol. 40, No. 20 (2002), pp. 2249-2264.
(7) Aouadi, M., Generalized Thermo-Piezoelectric Problems with Temperature-Dependent Properties, International Journal of Solids and Structures, Vol. 43 (2006), pp. 6347-6358.

(8) Sumi, N., Numerical Analysis for Piezothermoelastic Wave Propagations in Piezoelectric Plates, Transactions of the Japan Society of Mechanical Engineers, Series A, Vol. 70, No. 699 (2004),pp. 1588-1594.

(9) Hiki, Y., Elasticity and Inelasticity, (1972), pp. 130-133, Kyoritsu Shuppan (in Japanese).

(10) Lord, H. W. and Shulman, Y., A generalized Dynamical Theory of Thermoelasticity, Journal of the Mechanics and Physics of Solids, Vol. 15, No. 5 (1967), pp. 299-309.

(11) Sumi, N., Numerical Solutions of Thermoelastic Wave Problems by the Method of Characteristics, Joumal of Thermal Stresses, Vol. 24, No. 6(2001), pp. 509-530.

(12) Francis, P. H., Thermo-Mechanical Effects in Elastic Wave Propagation: A survey, Journal of Sound and Vibration, Vol. 21, No. 2 (1972), pp. 181-192. 